\title{
THE INFLUENCE OF SERVICE QUALITY TOWARD CUSTOMER LOYALTY: A CASE STUDY AT ALFAMART ABDURAHMAN SALEH BANDUNG
}

\author{
Rizki Faiz Al-Haqam'; Arif Yusuf Hamali² \\ ${ }^{1}$ ALFAMART Abdurahman Saleh, Bandung, \\ Jl. Abdurahman Saleh No. 21, Bandung, Jawa Barat, 40175, Indonesia \\ ${ }^{2}$ Politeknik PIKSI GANESHA, Bandung, \\ J1. Jend. Gatot Subroto 301, Bandung, Jawa Barat, 40274, Indonesia \\ 1'masterbedul@gmail.com; ${ }^{2}$ arifyusufhamali@yahoo.co.id
}

Received: $18^{\text {th }}$ March 2016/ Revised: $7^{\text {th }}$ May 2016/ Accepted: $14^{\text {th }}$ August 2016

How to Cite: Al-Haqam, R. F., \& Hamali, A. Y. (2016). The Influence of Service Quality toward Customer Loyalty: A Case Study at Alfamart Abdurahman Saleh Bandung. Binus Business Review, 7(2), 203-212.

http://dx.doi.org/10.21512/bbr.v7i2.1686

\begin{abstract}
The research objectives were to determine the correlation between service quality and customer loyalty, and also to analyze the influence of service quality on customer loyalty at Alfamart Abdurahman Saleh Bandung. Respondents of this research were 70 respondents with nonprobability sampling technique done by incidental sampling. The method used is descriptive and associative, which tested the connection using the Spearman rank correlation analysis, to test the hypothesis by t-test, and to determine the accuracy of measurement using the validity and reliability test. Results of the validity and reliability test of variables $\mathrm{X}$ and $\mathrm{Y}$ are valid and reliable. Calculations were performed using SPSS software ver. 19. The results of this research show that service quality is in the category of good and customer loyalty is also in the category of good. Results show that the correlation of service quality with customer loyalty at Alfamart Abdurahman Saleh Bandung is in the strong relation based on the interpretation of $\mathrm{r}$ value correlation coefficient. The hypothesis is proved that there is the influence of service quality on customer loyalty at Alfamart Abdurahman Saleh Bandung significantly.
\end{abstract}

Keywords: service quality, customer loyalty, correlation coefficient

\section{INTRODUCTION}

Marketing is essentially an activity aimed at establishing and maintaining customer who gives a benefit to the company, in addition to marketing is done to create a customer. Customer is an important factor that must be considered by the company because the customer is an asset that can determine company success. Customer will feel satisfied and loyal to the company if the company provides maximum service quality.

The customer who is not satisfied with the product or service received, by comparing the expected quality based on information received before purchasing a product so that the customer will make a response in the form of complaints or suggestions for improvement. Customer complaints have been delivered orally, by telephone or a direct visit to the company, and in writing by mail, SMS, or form of questionnaires distributed. The company must act quickly in responding to all complaints submitted by the customer to create maximum service quality. Previous research stated that service quality affected customer loyalty. The company management is need ed to emphasize on the program of customer satisfaction through a strategy centered on service quality to get customers who were loyal to the company in several industries, such as Airline (Yunus et al., 2013), Banking (Almsalam, 2014; Ashouri \& Lasibi, 2014; Anand \& Selvaraj, 2012; Ibojo, 2015; Kheng et al., 
2010; Esmailpour et al., 2012; Somasundaram \& Krishnamoorthy, 2013; Mosahab et al., 2010; Dewi, 2014; Islam, 2015), Mobile internet application (Roostika, 2011), Automotive (Jahanshahi et al., 2011); Utility (Agyapong, 2011), Retailing (Naik et al., 2010; Saidani, 2012; Ivanauskiene \& Volungenaite, 2014), and Telecommunication (Sabir et al., 2013; Akbar \& Parvez, 2009). In addition, customer satisfaction is needed in other industries such as Hotel (Setyorini, 2011; Al-Bostanji, 2013; Khan et al., 2014; Mirzapur et al., 2014), Pharmarcies, (Adoyo et al., 2012), Education (Rinala et al., 2013), Internet provider (Rizka \& Widji, 2013), Expedition (Quddus \& Hudrasyah, 2014), University Refectory (Saglik et al., 2014), Minimarket (Syarif et al., 2015), and Library Service (Wantara, 2015).

Alfamart minimarket is a provider of daily necessities of life, founded Djoko Susanto and family, with the name of Alfaria Trijaya Resources Tbk. (Alfamart). Business activity exponentially started in 2002 by acquiring 141 Alfaminimart stores with the new name of "Alfamart." Today Alfamart is one of the leaders in retail business, serving more than a lot of customers every day in more than 9,800 stores that spread in areas of Indonesia (Annual Report, 2014). Alfamart provides competitive prices, good quality in serving customers, and comfortable shopping atmosphere which is easily accessible.

The vision of Alfamart is to be the largest retail distribution network, which has the orientation in empowering small entrepreneurs and fulfilling customers' needs and expectations and has been capable to compete on a global scale. The missions of Alfamart are: (1) to satisfy customers' need by giving quality products and services; (2) to be the best in implementing ethical business practices; (3) to participate in building the spirit of entrepreneurship and business partnership; and (4) to be a reliable, healthy and global organization, that gives a benefit to the customers, suppliers, employees, stakeholders and Indonesian society in general.

Alfamart has a commitment called by "True Community Store." Alfamarts' commitment is to make the store as a place for shopping, by giving the competitive prices, quality products, good services, convenient store condition to the customers and always strive to provide the shopping information needed by customers. Alfamarts' marketing activities have been oriented in building company image, both in short and long-term marketing activities. One of the marketing activity in creating a customers' loyalty is in the form of shopping membership card called by "Ponta Card." Ponta stands for Point Terminal, a customer loyalty program that provides ease of shopping and collects points without having a lot of shopping membership cards, one card for everything.

Alfamart Abdurahman Saleh is one of Alfamart stores located at Jalan Abdurahman Saleh No. 21 Bandung City, West Java. The phenomenon of service quality that occurred in Alfamart based on information obtained from customers' complaints and initial research by conducting interviews with customers of Alfamart Abdurahman Saleh Bandung are presented in Table 1.

Table 1 Recapitulation of Customer Complaints between August 2015 - January 2016

\begin{tabular}{|c|c|}
\hline Customers' Complaint & $\begin{array}{l}\text { Number of } \\
\text { complaints }\end{array}$ \\
\hline $\begin{array}{l}\text { Lack of information about member card } \\
\text { as a service completeness tool }\end{array}$ & 40 \\
\hline $\begin{array}{l}\text { Employees' appearance is not neat, and } \\
\text { employee does not wear uniform while } \\
\text { on duty }\end{array}$ & 25 \\
\hline $\begin{array}{l}\text { Store room condition that makes } \\
\text { customers do not free to move on while } \\
\text { shopping }\end{array}$ & 30 \\
\hline \multirow{3}{*}{$\begin{array}{l}\text { Employees' attitude is less friendly and } \\
\text { less responsive in handling customer } \\
\text { complaints }\end{array}$} & 30 \\
\hline & \\
\hline & 125 \\
\hline
\end{tabular}

Source: The result of initial research on the customer of Alfamart Abdurahman Saleh Bandung, 2015-2016.

Data in Table 1 shows that complaints submitted by the customers who shop at Alfamart Abdurahman Saleh Bandung are still high enough in number. The complaints submitted by the customer also indicate that the service quality provided by employees of Alfamart have not been maximal to fulfill the customer expectations and needs.

Based on the explanation and data above, the analyzed problem can be formulated. First, it is how service quality and customer loyalty at Alfamart Abdurahman Saleh Bandung. Second, whether there is the influence of service quality toward customer loyalty at Alfamart Abdurahman Saleh Bandung significantly. The goal of this research is to find the relationship of service quality given by the company toward customer loyalty to keep shopping at Alfamart Abdurahman Saleh Bandung. The usefulness of this research is to find out the influence of service quality toward customer loyalty at Alfamart Abdurahman Saleh Bandung significantly.

The meaning of service quality started by the understanding of the term of quality defined from "zero defect," it means that doing it right for the first time (Parasuraman et al., 1985). Quality also means "conformance to requirements." Quality is measured by counting internal failures such as business activities before the product is sold, and external failures such as business activities after the product is sold.

Parasuraman et al. (1985) defined that service quality contains three fundamental understanding that must be acknowledged for all understanding of service quality, called by threewell-documented characteristics of service, namely: intangibility, heterogeneity, and inseparability. First, the characteristic of service is intangibility; it means that most services are intangible because service is a performance rather than objects. The service cannot be counted, measured, inventoried, 
tested, and verified in advance of sale to assure quality. Second, the characteristic of service is heterogeneity; it means that service is heterogeneous, a performance of service often varies in business activity. Third, the characteristic of service is inseparability; it means that production and consumption of many services are inseparable.

Service quality can be defined as three basic assumptions (Parasuraman et al., 1985). First, service quality is more difficult to be evaluated than goods quality. The consumer when purchasing goods employs many tangible cues to judge quality: style, hardness, color, label, feel, package, and fit, then when purchasing services, fewer tangible cues exist. Second, service quality perceptions came from a comparison between consumer expectations and actual service given by the company. It means that service quality is a measure of how well the services provided by the company in accordance with the wishes of the customer. Third, quality evaluations involve outcomes and processes. It means that the company must make a quality evaluations that is not only aimed at the results of the service but also the process of service provided to customers. Three dimensions of service performance involve the level of material, the level of facilities, and the level of personnel. The three dimensions of service performance are the notion that service quality involves not only the outcome but also the manner in delivering service to the customers.

The variable of service quality (SERVQUAL) consists of five dimensions (Parasuraman et al., 1988). The dimension of assurance and empathy are the items of the seven original dimensions consist of communication, credibility, security, competence, courtesy, understanding/knowing customers, and access; that did not remain distinct after the two stages of scale purification (Parasuraman et al., 1985). In the further development of the theory, quality of service only has five dimensions, namely (1) Tangibles: the physical evidence of the service, such as physical facilities, equipment, and employees' performance; (2) Empathy: caring, company's attention to its customers; (3) Reliability: ability to perform the promised service dependably and accurately; (4) Responsiveness: willingness to help customers in providing needed service; and (5) Assurance: the company's ability to provide assurance in after sales service to customers.

The dimensions of service quality analyzed in Alfamart Abdurrahman Saleh Bandung City are: (1) Tangible/physical evidence, consists of indicators like completeness of service tool in the form of shopping membership card, employees' appearance in duty, store facilities in selling products needed by customers, and store room condition; (2) Empathy, consists of indicators like employees understand the needs of customer and employees' friendly attitude to the customer; (3) Reliability, consists of indicators like speed in serving customers at the cashier and accuracy to provide services as promised in the form of shopping discount; (4) Responsiveness, consists of indicators like employees' cooperative attitude in responding to customer complaints and employees give quick response in following up customer complaints; and (5) Assurance, consists of indicators like customers' security while shopping in the store and availability of parking space for customers' vehicle.

The term customer loyalty is synonymous with the company's strategy to survive in the business competition. Loyalty or customer loyalty is closely related to customer satisfaction because customers feel satisfied with the purchase of a product or service, then the customer will be loyal to rebuy a product of the company (Oliver, 1999). Loyalty is described as a deeply held commitment to rebuy or re-patronize a preferred product/service consistently in the future, thereby causing same repetitive brand or same brand-set purchasing, despite situational influences and marketing efforts having the potential to cause switching behavior. The term customer loyalty is defined as a commitment held by the customer to rebuy a product or service consistently in the future, leading to rebuy the same brand.

Oliver (1999) stated that consumers could be "loyal" at each attitudinal phase relating to different elements of the attitude development structure. Customer will become loyal in a cognitive sense, then in an affective sense, still later in a conative manner, and finally in a behavioral manner called as "action inertia." Customer loyalty concept consists of cognitive loyalty, affective loyalty, conative loyalty, and action loyalty. Cognitive loyalty regards to customers' experience-based information. Affective loyalty regards to the loyalty development that reflects the pleasure dimensions of the satisfaction definition namely pleasurable fulfillment. Conative loyalty regards to customers' commitment to rebuy company product. The last customer loyalty is action loyalty, regards to action control of the customer, that is a loyalty state being transformed into the readiness of the customer for rebuying company product repeatedly.

Customer loyalty is defined as a positive experience and value of the customer for buying a product when the buying decision does not appear in a rational decision (Ganiyu et al., 2012). Companies should strive to gain customer loyalty by providing a memorable experience to customers on the company's business activities, by creating positive and emotional customers' experiences, until eventually customers become loyal to buy the company's products repeatedly. Loyal customers are often willing to pay premium prices, and they will recommend company's products and services to other people.

The dimensions of customer loyalty consist of both customers' attitudes and behaviors (Ganiyu et al., 2012). Customers' attitudinal component represents notions like repurchase intention or purchasing additional products or services from the same company, willingness of recommending the company to others, demonstration of such commitment to the company by exhibiting a resistance to switching to another competitor, and willingness to pay a price premium. The customers' behavior aspect represents actual 
repeat purchase of products or services that include purchasing more and different products or services from the same company, recommending the company to others, and reflecting a long-term choice probability for the brand. Typology of customers' behavior is primarily concerned with measures or repeat purchase and proportion of purchase. This typology does not include the customer's motives for their behavior, although this is considered to be a relevant measure.

The dimensions of customer loyalty analyzed at Alfamart Abdurrahman Saleh Bandung is customers' attitudes and behaviors. Dimension of customers' attitude consists of indicators like of customers' interest for shopping back to Alfamart and customers have been interested in shopping to competitors' minimarket. Dimension of customers' behavior consists of indicators like customers shop at Alfamart in large quantities with the available shopping discount, and customers recommend for shopping at Alfamart to all relationships.

Based on the descriptions that have been explained, the hypothesis can be formulated as follows: it is expected for service quality to influence customers' loyalty at Alfamart Abdurahman Saleh Bandung significantly. The conceptual framework of research is presented in Figure 1.

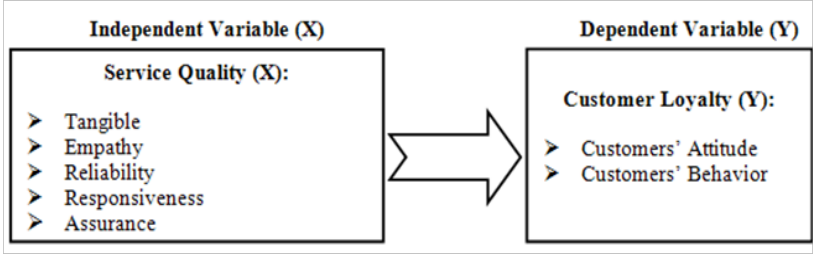

Figure 1 Conceptual Framework

\section{METHODS}

The method used in this research is descriptive and associative research. Descriptive research is research conducted to determine the value of an independent variable, either one or more variables (independent) without making comparisons or connecting between one variable with another variable (Sugiyono, 2011). Associative research is research that aims to determine the relationship between two or more variables, and build a theory which may serve to explain, to predict, and to control a symptom (Sugiyono, 2011).

The meaning of population is the generalization region consisting of the object/subject that has certain qualities and characteristics defined by the researchers to be studied and then to be concluded (Sugiyono, 2011). The population of this research is customers of Alfamart Abdurahman Saleh Bandung about 205 people, consist of customers who are frequently shopping to Alfamart Abdurahman Saleh Bandung and had a shopping card "Ponta." The sample is the part of population and characteristic possessed by this population (Sugiyono, 2011). The determination of sample in this research uses Slovin formula as follows:

$$
n=\frac{N}{1+N e^{2}}
$$

Description:

$\mathrm{n}=$ Sample

$\mathrm{N}=$ Population

$\mathrm{e}=$ the Percent of inaccuracy due to mistake in taking sample that can still be tolerated, taken $=10 \%$

$$
\begin{gathered}
n=\frac{205}{1+205(0.01)} \\
n=67,21 \text { rounded to } 70 \text { people }
\end{gathered}
$$

With $\mathrm{N}=205$ and $\mathrm{e}=10 \%$, it is obtained that $\mathrm{n}=67,21$ rounded to 70 , thus the sample is about 70 respondents. The technique of sampling done in this research is nonprobability sampling by incidental sampling technique, namely sampling technique based on chance, that anyone who by chance met with investigators can be used as a sample, when people (customers which shopping at Alfamart) who have been encountered by the researcher is suitable as a data source (Sugiyono, 2011). Data used in this research is primary source data and secondary data. Primary data is a collection of data done directly on the analyzed object to obtain the answers from the respondents. Secondary data is data obtained from organization, literature, and other information which considered relevant and supporting the research. Method used to collect data is closed system questionnaire. It means, for each question has been available with the answer. Questionnaire used in this research is Likert scale. The scale is made by gradation from strongly disagree $($ score $=1)$ to strongly agree $($ score $=5)$.

Analysis taken in this research is descriptive and associative. Descriptive analysis using a weighted analysis, and to find the standard weight value can be done by looking for the length of the weight range. The standard weight value can be determined by looking for the length of weight range of five classifications, with the step as follows:

$$
\begin{gathered}
R=\frac{B_{\text {maks }}-B_{\min }}{5} \\
R=\frac{(5 \times 70)-(1 \times 70)}{5} \\
R=56
\end{gathered}
$$

Description:

$\mathrm{R}=$ the range of classification

Bmaks = maximum weight of answer

Bmin = minimum weight of answer

The weighting is divided into five levels based on the classification above, started from the lowest to the highest level with the long range above 56. The classification is the standard weight value generated is as follows: 
Table 2 The Standard Weight Value

\begin{tabular}{cc}
\hline Weight Value & Category \\
\hline $70-125$ & Worst \\
$126-181$ & Worse \\
$182-237$ & Enough \\
$238-293$ & Good \\
$294-350$ & Best \\
\hline
\end{tabular}

(Source: the result of processing primary data, 2016)

Associative analysis is done to see how the influence of independent variable on dependent variable, in this case, the influence of service quality (X) toward customer loyalty (Y) at Alfamart Abdurahman Saleh Bandung, by using the formula of Rank Spearman as follows:

$$
r_{s}=1-\left[\frac{6 \sum d_{i}{ }^{2}}{N^{3}-N}\right]
$$

where:

$\mathrm{r}_{\mathrm{s}}=$ correlation analysis

$\mathrm{d}_{\mathrm{s}}=$ difference of two variable

$\mathrm{N}=$ sample

The test of correlation coefficient is done to find out the truth of hypothesis presented in this research by using t-test formula:

$$
t=r \sqrt{\frac{N-2}{1-r^{2}}}
$$

where:

$\mathrm{R}=$ correlation coefficient

$\mathrm{N}=$ sample

T-test is performed to prove that service quality variable (X) affects customer loyalty variable (Y) significantly, with provision as follows:
If $t_{\text {count }}>t_{\text {table }}$, then service quality affects customer loyalty significantly, or Ho is rejected, and $\mathrm{Ha}$ is accepted.

If $\mathrm{t}_{\text {count }}<\mathrm{t}_{\text {table }}$, then service quality does not affect customer loyalty significantly, or Ho is accepted and $\mathrm{Ha}$ is rejected.

The calculation in data analysis of this research uses SPSS Software version 19. The next step is analyzing the correlation to see the influence of service quality toward customer loyalty by using Coefficient Determination with this formula:

$\mathrm{KD}=\mathrm{r}^{2} \times 100 \%$

Correlation or tightness of the relationship between independent variable and dependent variable is classified by Riduwan and Kuncoro (2007) presented in Table 3 as follows

Table 3 Interpretation of Correlation Coefficient of $r$ Value

\begin{tabular}{cc}
\hline Interval of Coefficient & Level of Relation \\
\hline $0,80-1,000$ & Very strong \\
$0,60-0,799$ & Strong \\
$0,40-0,599$ & Strong enough \\
$0,20-0,399$ & Weak \\
$0,00-0,199$ & Very weak \\
\hline
\end{tabular}

(Source: Riduwan \& Kuncoro, 2007)

\section{RESULTS AND DISCUSSIONS}

The result of validity test on the instrument of service quality variable (X) and customer loyalty variable $(\mathrm{Y})$ states all is valid, based on the criteria if coefficient of correlation or $r$ count $>0,3$ with significance degree $5 \%(\alpha=5 \%)$, then the statement is valid. The result of validity test on service quality variable and customer loyalty variable is shown in Table 4 and Table 5.

\begin{tabular}{|c|c|c|c|}
\hline Dimensions & Questions & $\begin{array}{c}\mathbf{r} \\
\text { count }\end{array}$ & Result \\
\hline \multirow[t]{4}{*}{ Tangible } & Completeness of service tool in the form of shopping membership card & 0,334 & Valid \\
\hline & Employees' appearance in duty & 0,755 & Valid \\
\hline & Store facilities in selling products needed by customers & 0,753 & Valid \\
\hline & Store room condition & 0,744 & Valid \\
\hline \multirow[t]{2}{*}{ Empathy } & Employees understand the needs of customer & 0,837 & Valid \\
\hline & Employees' friendly attitude to the customer & 0,728 & Valid \\
\hline \multirow[t]{2}{*}{ Reliability } & Speed in serving customers at the cashier & 0,756 & Valid \\
\hline & Accuracy to provide services as promised in the form of shopping discount & 0,722 & Valid \\
\hline \multirow[t]{2}{*}{ Responsiveness } & Employees' cooperative attitude in responding to customer complaints & 0,690 & Valid \\
\hline & Employees give quick response in following up customer complaints & 0,728 & Valid \\
\hline \multirow[t]{2}{*}{ Assurance } & Customers' security while shopping in the store & 0,841 & Valid \\
\hline & Availability of parking space for customers' vehicle & 0,786 & Valid \\
\hline
\end{tabular}

Table 4 Validity Test for Service Quality Variable (X)

(Source: the result of processing primary data, 2016) 
Table 5 Validity Test for Customer Loyalty Variable (Y)

\begin{tabular}{|c|c|c|c|}
\hline Dimensions & Questions & $r$ count & Description \\
\hline \multirow{2}{*}{ Customers'Attitude } & Customers' interest for shopping back to Alfamart & 0,813 & Valid \\
\hline & Customers have been interested in shopping to competitors' minimarket & 0,898 & Valid \\
\hline \multirow[t]{2}{*}{ Customers' Behavior } & $\begin{array}{l}\text { Customers shop at Alfamart in large quantities with the available } \\
\text { shopping discount }\end{array}$ & 0,829 & Valid \\
\hline & Customers recommend for shopping at Alfamart to all relationships & 0,813 & Valid \\
\hline
\end{tabular}

(Source: the result of processing primary data , 2016)

The result of reliability test on the instrument of service quality variable (X) and customer loyalty variable $(\mathrm{Y})$, states that all is reliable, based on the assessment criteria on coefficient $\alpha$ - Cronbach, if $>0,7$ is categorized reliable (Sugiyono, 2011). The result of reliability test on service quality variable and customer loyalty variable is shown in Table 6 and Table 7.

Table 6 The Result of Reliability Test on Service Quality Variable (X)

$\begin{array}{r}\text { TEST OF RELIABILITY - } \\ \text { R C A L E (A L P H A) } \\ \text { Reliability Coefficients } \\ \text { N of Cases }=\quad 70,0 \quad \text { N of Items }=12 \\ \text { Alpha }=0,917 \\ \hline\end{array}$

(Source: the result of processing primary data, 2016)

Table 7 The Result of Reliability Test on Customer Loyalty Variable (Y)

\begin{tabular}{c} 
TEST OF RELIABILITY - \\
R C A L E \\
Reliability Coefficients \\
N of Cases $=\quad \begin{array}{l}70,0 \\
\text { Alpha }=0,857\end{array}$ \\
\hline
\end{tabular}

(Source: the result of processing primary data, 2016)

The result of descriptive the average weighting for service quality variable shows the average value of weight about 279, based on the classification range is in the good category. This result can be concluded that overall service quality at Alfamart Abdurahman Saleh Bandung has been good given to the customers which shop at the store. However, there is a dimension that weight value is below the average weighting value of service quality variable; that is the dimension of tangible with the average value about 253 . The indicators that weight value is below the average weighting value of service quality variable, that is the completeness of service tool, store room condition, and store room condition. This result indicates that the respondents as customers of Alfamart Abdurahman Saleh Bandung argued that the completeness of service tool in the form of shopping member card has not been fully known by the customer. Customers argued that the shopping member card has never been informed and socialized to customers so that customers have never gotten a benefit of the shopping member card as the completeness of service tool. Customers' opinion on the indicator of employees' appearance is that employees' appearance is not maximal yet assessed by the customers because there is still undisciplined employee who do not wear working uniform and there is still employee who has not been neat yet in dress. Customers' opinion on indicator of store room condition is that the shelves for putting on the products sold in the store are placed inefficient so that it make the store room felt narrow and the customers feel uncomfortable and can not move freely while shopping.

Other indicators that the average value is below the weight value of service quality variable is employees' friendly attitude to the customers on dimension of empathy; indicator of accuracy to provide services as promised in the form of shopping discount on dimension of reliability; and indicator of employee give quick response in following up customer complaints on dimension of responsiveness. Respondents' opinion on indicator of employees' friendly attitude to the customers is that the employees have not given yet their empathy to customers which come for shopping to Alfamart Abdurahman Saleh Bandung. Empathy in the form of employees' friendly attitude is not maximal yet given to customers is smiling and greeting in welcoming customers when at first time they walk into the store and saying thanks that accompany the customers walk out of the store after making payment at the cashier. Indicator of accuracy to provide services as promised in the form of shopping discount on dimension of reliability is not fully realized yet according to customers. Shopping discount program that is promised could not be applied every day when the customer comes to shopping, and the shopping discount is only a promotional package that could only be applied at a certain period of time, and also the discount could not be given to all of the products. The last indicator is employees give quick response in following up customer complaints on dimension of responsiveness, assessed by the customer that employees have not been responsive yet in following up customers' complaints. Grievances are often submitted by customers are the differences between the sale price printed on price tag on the shelves with the product selling price is inputted in the cashier computer. Employees are on duty does not respond quickly to provide solution of determining 
where the price is right, whether the price is on the label of the shelves or the price is inputted in the cashier computer, then finally the customer pays for the products purchased based on the price inputted in the computer cashier. The result of descriptive average weight on respondents' opinion about service quality variable at Alfamart Abdurahman Saleh Bandung, is presented in Table 8.

Table 8 Respondents' Opinion about Service Quality Variable (X)

\begin{tabular}{cc}
\hline Dimension & Weight \\
\hline Tangible & 253 \\
Empathy & 283 \\
Reliability & 281 \\
Responsiveness & 298 \\
Assurance & 282 \\
\hline Average & $\mathbf{2 7 9}$ \\
\hline
\end{tabular}

(Source: the result of processing primary data, 2016)

The result of descriptive average weighting for customer loyalty variable shows average value of weight about 275 , based on classification ranges is in the good category. This result shows that overall Alfamart Abdurahman Saleh Bandung has fulfilled most of the expectations and needs of customers. However, there are dimensions that are below the average value of weight of customer loyalty variable that is dimension of customers' behavior on indicator of customers shop at Alfamart in large quantities with the available shopping discount, with average value about 263. This result shows that respondents as a customer of Alfamart Abdurahman Saleh Bandung argued that customers actually want to buy products that are needed in large quantities, but customers' expectation and desire to get the discount of the purchased products have not been fully realized by the store. Discounts' program promised by Alfamart with the ownership of shopping membership card has not been fully realized to the customer when shopping, because the discounts' program is only valid at certain times, and only on certain products which are given a discount, so that this provision makes customers are reluctant for shopping in large quantities. The ownership of shopping membership cards with product discount promised, deemed not providing significant benefits for customers. The result of descriptive average weighting of respondents' opinion on customer loyalty variable at Alfamart Abdurahman Saleh Bandung is presented in Table 9.

The influence of service quality on customer loyalty at Alfamart Abdurahman Saleh Bandung can be viewed using Spearman's Rank correlation analysis. The result of correlation analysis by using SPSS version 19 , with $\mathrm{r}$ value $=0,718$ is shown in Table 10.

The result of SPSS in Table 10 shows that the result is significant on significance level $\alpha=5 \%$ (value sig. (2-tailed) $=0,000$ is smaller than $5 \%$ ), which means there is an influence of service quality toward customer loyalty significantly at Alfamart Abdurahman Saleh Bandung. The hypothesis test is done to find out the truth of hypothesis presented in this research by using t-test, as follows:

Table 9 Respondents' Opinion about Customer Loyalty Variable (Y)

\begin{tabular}{clcc}
\hline Dimension & & Indicator & Weight \\
\hline Customers' Attitude & Customers' interest for shopping back to Alfamart & 275 \\
& Customers have been interested in shopping to competitors' minimarket & 278 \\
Customers' Behavior & Customers shop at Alfamart in large quantities with the available shopping discount & 263 \\
& & Customers recommend for shopping at Alfamart to all relationships & 283 \\
\hline & & Average & $\mathbf{2 7 5}$ \\
\hline
\end{tabular}

(Source: the result of processing primary data, 2016)

Table 10 Correlation Analysis (Nonparametric Correlation)

\begin{tabular}{|c|c|c|c|c|}
\hline \multicolumn{5}{|c|}{ Correlations } \\
\hline & & & Service Quality & Customer Loyalty \\
\hline \multirow{6}{*}{ Spearman's rank } & \multirow{3}{*}{ Service Quality } & Coefficient of Correlation & 1,000 & $0,718^{* *}$ \\
\hline & & Sig. (2-tailed) & - & 0,000 \\
\hline & & $\mathrm{N}$ & 70 & 70 \\
\hline & \multirow{3}{*}{ Customer Loyalty } & Correlation Coefficient & $0,718^{* *}$ & 1,000 \\
\hline & & Sig. (2-tailed) & 0,000 & . \\
\hline & & $\mathrm{N}$ & 70 & 70 \\
\hline
\end{tabular}

**. Correlation is significant at the 0.01 level (2-tailed).

(Source: the result of processing primary data, 2016) 


$$
t=r \sqrt{\frac{N-2}{1-r^{2}}}
$$

Where:

$$
\begin{aligned}
& \mathrm{r}=0,718 \\
& \mathrm{~N}=70 \\
& t=0,718 \sqrt{\frac{70-2}{1-(0,718)^{2}}} \\
& \mathrm{t}=8,51
\end{aligned}
$$

The value of $t$ count is compared to $t$ table, based on the table of distribution that $\mathrm{t}$ for $\mathrm{db}=70-2=68$, $\alpha=0,05$. For the the test of two parties, it is obtained $\mathrm{t}=2,000$. The calculation shows the value of $\mathrm{t}$ count is bigger than value of $\mathrm{t}$ table which is $8,51>2,000$; then $\mathrm{Ho}$ is rejected, and $\mathrm{Ha}$ is accepted. Therefore, the hypothesis presented in this research is right, which means service quality affects customer loyalty significantly at Alfamart Abdurahman Saleh Bandung. Next is to find out the relation level, based on the interpretation of correlation coefficient of $r$ value in Table 3, with $\mathrm{r}$ value $=0,718$, then this relation is in strong relation criteria. From this result $r=0,718$, next step is to show contribution of service quality variable (X) toward customer loyalty variable (Y), determined by Coefficient of Determination (CD) as follows:

$$
\begin{aligned}
\mathrm{CD} & =\mathrm{r}^{2} \times 100 \% \\
& =(0,718)^{2} \times 100 \%=51,55 \%
\end{aligned}
$$

Based on the calculation, with $51,55 \%$, it means that service quality has an influence toward customer loyalty at Alfamart Abdurahman Saleh Bandung about $51,55 \%$, while the rest about $48,45 \%$ is influenced by other factors that are not examined in this research.

\section{CONCLUSIONS}

The result of this research can be concluded that there is a correlation between service quality toward customer loyalty at Alfamart Abdurahman Saleh Bandung significantly. Based on Spearman Rank correlation analysis, it is obtained correlation coefficient $\mathrm{r}=0,718$. Based on the interpretation of the correlation coefficient $r$ value (Riduwan \& Kuncoro, 2007), with the value of $r=0,718$, then this relationship is categorized as strong. From Coefficient of Determination (CD), it is obtained $\mathrm{r}^{2}=0,5155$; it means that in this research, service quality affects customer loyalty about $51,55 \%$, while the rest about $48,45 \%$ is affected by other factors that are not analyzed in this research. The result of hypothesis test using t-test at $\alpha=0,05$ for the test of two parties, shows the value of $t$ count is larger than the value of t-table $(8,52>2,000)$. Thus Ho is rejected, and $\mathrm{Ha}$ is accepted. Those results approve the hypothesis in this research that there is positive and significant effect on service quality on customer loyalty at Alfamart Abdurahman Saleh Bandung.

There are several suggestions that can be given to the company. First, the company's top management should further improve service quality to customers which shop at Alfamart, by meeting the expectations and needs of customers, and realize service products promised by the company. Second, the company should be more active to socialize the product of Alfamart's shopping membership card and realize the benefit the shopping card like shopping discount that is valid for all shopping products and without being limited the period of time. Third, the placement of the shelves to put the products sold in the store should be organized more efficiently in the minimalist room, so that customers can move freely while shopping and it makes the customer feel comfortable to come back for shopping to Alfamart Abdurahman Saleh Bandung. Fourth, employees are on duty should continually strive to provide superior service to the customers by showing the work professionalism to keep discipline in wearing work uniform with neat and polite according to the rules of work determined by the company. Fifth, the management of Alfamart should give work directions to employees for being friendly to customers by providing welcome smile and greet the customers which come for shopping, to say thank you after the customer has finished the payment at the cashier, and open the door when the customer walk to the exit. Sixth, the management of Alfamart should provide work instruction to employees to renew the product selling price which is printed on the price tag of the shelves and adjust to the up to date product selling price that have been set by the management and inputted in the cashier computer, so that the different product selling price does not harm the customers and make the customers switch to competitors' minimarket.

The result of this research shows that service quality influence customer loyalty about 51,55\% while the rest about $48,45 \%$ is influenced by another factors that are not examined in this research, so it can be suggested for the future researchers, they can conduct a research by adding different independent variabel $(\mathrm{X})$, such as brand image, promotion strategy, or pricing strategies which can affect customer loyalty.

\section{REFERENCES}

Adoyo, B., Ondoro, C. O., \& Aila, F. O. (2012). The Relationship between Customer Service Quality and Customer Loyalty among Retail Pharmacies in Western Kenya, International Journal Management Business Research, 2(3), 11-21.

Agyapong, G. K. Q. (2011). The Effect of Service Quality on Customer Satisfaction in the Utility Industry - A Case of Vodafone (Ghana). International Journal of Business and Management, 6(5), 203-210.

Akbar, M. M., \& Parvez, N. (2009). "Impact of Service Quality, Trust, and Customer Satisfaction on 
Customer Loyalty", ABAC Journal, 29(1), 24-38.

Alfamart. (2014). Continuing Service Excellence", Laporan Tahunan (Annual Report) PT Sumber Alfaria Trijaya Tbk.

Almsalam, S. (2014). The Effects of Customer Expectation and Perceived Service Quality on Customer Satisfaction Samaan Almsalam. International Journal of Business and Management Invention, 3(8), 79-84.

Anand, S. V., \& Selvaraj, M. (2012). The Impact of Service Quality on Customer Satisfaction and Loyalty in Indian Banking Sector: An Empirical Study through SERVPERF. International Journal Management Business Research, 2(2), 151-163.

Ashouri, T., \& Lasibi, M. Z. (2014). The Effect of Electronic Service Quality on Customer Loyalty. Kuwait Chapter of Arabian Journal of Business and Management Review, 3(11), 121-129.

Dewi, G. A. P. R. K. (2014). Pengaruh Kualitas Pelayanan Terhadap Kepuasan Dan Loyalitas Nasabah PT. BPR Hoki Di Kabupaten Tabanan (Undergraduate's thesis). Universitas Udayana, Denpasar, Indonesia.

Esmailpour, M., Zadeh, Ma. B., \& Hoseini, E. H. (2012). The Influence of Service Quality on Customer Satisfaction: Customers of Boushehr Bank Sepah as a Case Study. Interdisciplinary Journal of Centemporary Research In Business, 3(9), 11491159.

Ganiyu, R. A., Uche, I. I., \& Elizabeth, A. O. (2012). Is Customer Satisfaction an Indicator of Customer Loyalty? Australian Journal of Business and Management Research, 2(7), 14-20.

Islam, S. (2015). Impact of service quality on customer loyalty: a case study of commercial banks in Dhaka, Bangladesh. International Journal of Business, Management and Social Research, 1(2), 51-60.

Ivanauskien, N., \& Volung, J. (2014). Relations between Service Quality and Customer Loyalty: An Empirical Investigation of Retail Chain Stores in Emerging Markets Neringa Ivanauskien è Doctor of Social Sciences Vice-Dean for Academic Affairs ISM University of Management and Economics Master. American International Journal of Social Science, 3(2), 113-120.

Jahanshahi, A. A., Gashti, M. A. H., Mirdamadi, S. A., Nawaser, K., \& Khaksar, S. M. S. (2011). Study the Effects of Customer Service and Product Quality on Customer Satisfaction and Loyalty. International Journal of Humanities and Social Science, 1(7), 253-260.

Khan, M. M., \& Fasih, M. (2014). Impact of Service Quality on Customer Satisfaction and Customer Loyalty: Evidence from Banking Sector. Pakistan Journal of Commerce and Social Sciences, 8(2), 331-354.

Kheng, L. L., Mahamad, O., Ramayah, T., \& Mosahab, R. (2010). The Impact of Service Quality on Customer Loyalty: A Study of Banks in Penang, Malaysia. International Journal of Marketing Studies, 2(2), $57-66$.

Mirzapur, Fatemeh., Akhlagh, Esmael Malek., \& Taleghani, Mohammad. (2014). Impact of Service Quality on
Customers Loyalty with Emphasis on Customer Satisfaction Indez Model (CSI), (Case Study: Parsian Bank of Guilan Province)", Universal Journal of Management and Social Sciences, 4(10), 1-9.

Mohammed, G., \& Bostanji, A. (2013). The Impact of Service Quality on Customers Loyalty A Study on five stars hotel's customers in Riyadh, KSA. European Journal of Business and Management, 5(31), 230-241.

Mosahab, R., Mahamad, O., \& Ramayah, T. (2010). Service Quality, Customer Satisfaction and Loyalty: A Test of Mediation. International Business Research, 3(4), $72-80$.

Naik, C. N. K., Gantasala, S. B., \& Prabhakar, G. V. (2010). "Service Quality and Its Effect on Customer Satisfaction in Retailing". European Journal of Social Sciences, 16(2), 231-243.

Odunlami, B., \& Matthew, O. (2015). Impact of Customer Satisfaction on Customer Loyalty: A Case Study of a Reputable Bank in Oyo, Oyo State, Nigeria. International Journal of Managerial Studies and Research (IJMSR), 3(2), 59-69.

Oliver, R. L. (1999). Whence Consumer Loyalty. Journal of Marketing, 63(Special Issue), 33-44.

Oliver, R. L. (1988). "SERVQUAL: A Multiple-Item Scale for Measuring Consumer Perceptions of Service Quality", Journal of Retailing, 64(1), 12-40.

Parasuraman, A., Zeithaml, V. A., \& Berry, L. (1985). A conceptual model of service quality and its implications for future research. Journal of Marketing, 49(1979), 41-50.

Quddus, F. S., \& Hudrasyah, H. (2014). The Influence of Service Quality Dimensions on Customer Satisfaction and Customer Loyalty in PT JNE North Bandung Area. Journal of Business and Management, 3(5), 546-556.

Riduwan \& Kuncoro, E. A. (2007). Cara Menggunakan dan Memaknai Analisis Jalur (Path Analysis). Cetakan ke-1. Bandung: Alfabeta.

Rinala, I. N., Yudana, I. M., \& Natajaya, I. N. (2013). Pengaruh Kaulitas Pelayanan Akademik terhadap Kepuasan dan Loyalitas Mahasiswa pada Sekolah Tinggi Pariwisata Nusa Dua Bali. Journal Program Pascasarjana Universitas Pendidikan Ganesha, 4.

Rizka, M., \& Widji, A. (2013). Customer Loyalty the Effects of Service Qualityand The Mediating Role of Customer Relationship Marketing Telkom Speedy in Jember Area. Society of Interdisciplinary Business Research, 2(1), 491-502.

Roostika, R. (2011). The Effect of Perceived Service Quality and Trust on Loyalty: Customer's Perspectives on Mobile Internet Adoption. International Journal of Innovation, Management and Technology, 2(4), 286-291.

Sabir, R. I., Muhammad, I., Sarwar, M. A., Sarwar, B., \& Akhtar, N. (2013). The Impact of Service Quality, Customer Satisfaction and Loyalty Programs on Customer's Loyalty: An Evidence from Telecommunication Sector. Journal of Asian Business Strategy, 3(11), 306-314.

Saglik, E., Gallucu, A. C., Kaya, U., \& Ozhan, C. K. 
(2014). Service Quality and Customer Satisfaction Relationship: A Research in Erzurum Ataturk University Refectory. American International Journal of Contemporary Research, 4(1), 100-117.

Saidani, B. (2012). Pengaruh Kualitas Produk dan Kualitas Layanan terhadap Kepuasan Konsumen dan Minat Beli pada Ranch Market. Jurnal Riset Manajemen Sains Indonesia, 3(1), 1-22.

Setyorini, W. (2011). Pengaruh Kualitas Pelayanan terhadap Loyalitas Pelanggan pada Hotel Mahkota di Pangkalan Bun. Socioscientia Jurnal Ilmu-Ilmu Sosial, 3(1), 167-178.

Somasundaram, R., \& Krishnamoorthy, V. (2013). Impact of Service Quality on Customer Relationship Management in the Banking Sector. International Monthly Refereed Journal of Research In Management \& Technology, 2(5), 102-110.
Sugiyono. (2011). Metode Penelitian Administrasi. Cetakan ke-19. Bandung: Alfabeta.

Syarif, N., Salman., \& Rewindinar. (2015). Pengaruh Brand Activation Alfamart dan Indomart dalam Membangun Loyalitas Konsumen. Kalbi Socio Jurnal Bisnis dan Komunikasi, 2(1), 87-97.

Wantara, P. (2015). The Relationships among Service Quality, Customer Satisfaction, and Customer Loyalty in Library Services. International Journal of Economic and Financial Issues, 5(Special Issue), 264-269.

Yunus, N. S. N. M., Bojei, J., \& Rashid, W. E. W. (2013). Service Quality towards Customer Loyalty in Malaysia's Domestic Low Cost Airline Services. International Journal of e-Education, e-Business, e-Management and e-Learning, 3(4), 333-336. 